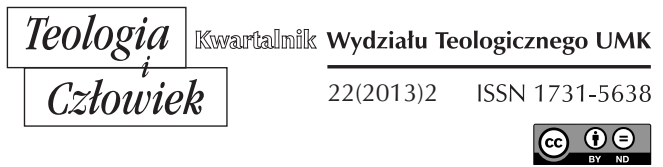

KS. MAREK KLUZ*

TARNÓW-KRAKÓW

\title{
INTEGRUJĄCA ROLA MIŁOŚCI WE WSPÓLNOCIE ŻYCIA MAŁŻEŃSKIIEGO
}

DOI: http://dx.doi.org/10.12775/TiCz.2013.014

\section{WSTĘP}

Na obraz Boga, który jest Miłością (1 J 4,8), powołanie do miłości jest częścią wewnętrznego dynamizmu bytu ludzkiego. Człowiek został stworzony do miłości. „Bóg [...], powołując go do istnienia z miłości, powołał go jednocześnie do miłości [...]. Miłość jest zatem podstawowym i wrodzonym powołaniem każdej istoty ludzkiej"1. Osoba ludzka osiąga swoją doskonałość, realizuje siebie jako osoba poprzez relację do innych, o ile owa relacja jest wyrazem miłości.

Jednym ze sposobów urzeczywistniania powołania osoby ludzkiej do miłości jest małżeństwo. Małżeństwo jest autentycznym związkiem

* Ks. dr hab. Marek Kluz - adiunkt Katedry Teologii Moralnej i Duchowości Wydziału Teologicznego Sekcja w Tarnowie Uniwersytetu Papieskiego Jana Pawła II w Krakowie, sekretarz WTST. Autor kilku książek i ponad 60 artykułów naukowych poświęconych moralności małżeńsko-rodzinnej, wychowania moralnego, bioetyce, moralności życia społecznego i działalności socjalno-charytatywnej.

${ }^{1}$ Jan Paweł II, Adhortacja apostolska „Familiaris consortio", Watykan 1981, nr 11 (dalej: FC). 
dwojga osób, o ile ożywa je wzajemne obdarowanie miłością. Bez miłości małżeństwo nie może się egzystencjalnie zrealizować. Sobór Watykański II stwierdza otwarcie, że miłość jest „centrum małżeństwa i życia małżeńskiego"2 ${ }^{\prime 2}$ Na ten sam aspekt wskazał też Jan Paweł II i Benedykt XVI, uwydatniając fakt, że miłość powinna być zawsze początkiem i siłą komunii i wspólnoty małżeńskiej3. Miłość jest jednym z najgłębszych źródeł małżeńskiej wspólnoty i gwarantem ludzkiego szczecią na ziemi.

Niestety, współczesna mentalność przyczynia się do degradacji wartości miłości w życiu małżeńskim. Szczególnie przekaz medialny pokazując m.in. różne seriale często zniekształca obraz prawdziwej miłości małżeńskiej. Nie można jednak dopuścić, by miłość małżeńska była profanowana przez egoizm, zdradę, przez poszukiwanie za wszelką cenę przyjemności, przez zamknięcie się na życie. „Brak prawdziwej miłości w relacjach międzyludzkich - miłości wyłącznej, nierozerwalnej, aż po śmierć - jest straszliwie destrukcyjną siłą, trywializująca, a ostatecznie niszczącą nie tylko poszczególne osoby, ale same podstawy życia społecznego"4.

W tej perspektywie słusznym wydaje się - w duchu miłości i odpowiedzialności za Ojczyznę, Kościół i świat - podjęcie niejako na nowo refleksji na temat integrującej roli miłości w życiu małżeńskim. Chodzi bowiem o to, aby dopomóc małżonkom odkryć piękno i wielkość ich powołania, by zapragnęli nim żyć w całej pełni. Chodzi też o to, by pomóc zagrożonym małżeństwom wrócić do pierwotnej miłości, a pozostałe uchronić od niebezpieczeństw. W końcu chodzi również o to, aby młodzi ludzie, którzy dopiero wchodzą w życie, zrozumieli, że muszą od siebie wymagać przede wszystkim wtedy, gdy przychodzi miłość i gdy myślą o małżeństwie i rodzinie. Gdy reklama dóbr materialnych zda się osiągać szczyt nachalności, trzeba przebić się z orędziem, że miłość istnieje i że jest najważniejsza (por. 1 Kor 13,13). Taki też cel przyświeca niniejszej publikacji.

2 Sobór Watykański II, Konstytucja duszpasterska o Kościele w świecie wspótczesnym "Gaudium et spes", w: Sobór Watykański II, Konstytucje. Dekrety. Deklaracje, Poznań 1968, nr 49 (dalej: KDK).

${ }^{3}$ Por. FC 18; Benedykt XVI, Encyklika „Deus caritas est”, Rzym 2005, nr 2, 11 (dalej: DCE).

${ }^{4}$ Rada ds. Rodziny Konferencji Episkopatu Polski, Stużyć prawdzie o matżeństwie i rodzinie, Warszawa 2009, nr 10. 


\section{MIŁOŚĆ JAKO PERSPEKTYWA DARU}

Człowiek może odnaleźć siebie i sens swojego życia jedynie w horyzoncie określonym przez miłość. Papież Jan Paweł II w encyklice Redemptor hominis podkreślił to wyraźnie: "Człowiek nie może żyć bez miłości. Człowiek pozostaje dla siebie istotą niezrozumiałą, jego życie jest pozbawione sensu" ${ }^{\prime 5}$. Osoba jest bowiem takim bytem, że właściwe i pełnowartościowe odniesienie do niej stanowi miłość. Także prawdziwe poznanie w relacjach międzyludzkich jest możliwe tylko w miłości i dzięki miłości. Dlatego należy przyjrzeć się temu, czym jest miłość i jaka winna być ona w małżeństwie.

Nie ulega wątpliwości, że ludzie współcześni tęsknią do prawdziwej miłości, szukają jej, przeżywają dramat niespełnionej miłości, a jednocześnie tak łatwo dają się porwać mirażom miłości „bylejakiej”, tak łatwo sięgają po namiastki miłości. Rozczarowani do tych namiastek tak często mówią: „nie wierzę w miłość".

Podejście do miłości w dzisiejszym świecie ma wyraźnie charakter ambiwalentny. Z jednej strony podkreśla się dzisiaj między innymi znaczenie miłości małżeńskiej, kładzie się szczególny akcent na partnerstwo w tej miłości, można mówić o większym wyczuleniu na różne aspekty miłości społecznej itp. Z drugiej strony - jakże często sprowadza się miłość do czegoś, co nie jest godne zwać się miłością.

Mentalność współczesna sprawia, że tak łatwo popada się w pewne skrajności $\mathrm{w}$ pojęciu miłości. I tak $\mathrm{w}$ ramach nastawienia intelektualistycznego czy racjonalistycznego $\mathrm{w}$ zasadzie nie docenia się prawdziwego znaczenia miłości, gdyż człowieka ocenia się jedynie pod kątem jego zdolności techniczno-racjonalnych. Natomiast współczesne tendencje określane mianem witalizmu rodzą postawy użycia i wyżycia się, a nawet pewnej brutalności, co z kolei na płaszczyźnie miłości prowadzi do takich między innymi zjawisk jak tzw. seksualizm, który zniekształca i niszczy miłość osobową. Witalizm sprawia, że człowiek nie jest zdolny do prawdziwego rozumienia miłości (miłość jest niejako częścią konsumpcji, zaspokojenia swoich potrzeb) ${ }^{6}$. W tej perspektywie należy się zastanowić i rozważyć, czym jest prawdziwa miłość i po czym poznać, że to, co jest deklarowane jako miłość, tą miłością jest.

5 Jan Paweł II, Encyklika "Redemptor hominis", Warszawa 1979, nr 10.

${ }^{6}$ Por. A. Bohdanowicz, Istota miłości i jej postaci, „Teologia i Moralność” 4 (2008), s. 26. 
Wydaje się, że kluczowym tekstem dla odczytania istoty ludzkiej miłości jest soborowa Konstytucja duszpasterska o Kościele w świecie współczesnym Gaudium et spes. Dokument ten stwierdza, że człowiek jest taką istotą, która odnajduje się w pełni tylko poprzez bezinteresowny dar $\mathrm{z}$ siebie samego ${ }^{7}$. W miłości zatem ważny jest ktoś inny, ktoś komu trzeba się dać. W tym kierunku podąża też nauczanie papieża Jana Pawła II i Benedykta XVI.

Jan Paweł II bardzo często odwoływał się do tekstu z Konstytucji Gaudium et spes nr 24. W stwierdzeniu, że człowiek odnajduje się i spełnia poprzez obdarowanie sobą innych, widział streszczenie całej chrześcijańskiej antropologii. W liście apostolskim Mulieris dignitatem podkreślił on, że „być osobą - to znaczy: dążyć do samospełnienia, które nie może dokonać się inaczej, jak tylko «poprzez bezinteresowny dar z siebie samego» [...]. Człowiek jest wezwany do tego, aby bytować 'dla' drugich, aby stawać się darem" ${ }^{\prime \prime}$. W książce Przekroczyć próg nadziei Jan Paweł II zaznaczył, że omawiany tekst soborowy stanowi pełną interpretację personalistyczną przykazania miłości. Zawiera jasno sformułowaną zasadę afirmacji osoby, ze względu na to, że jest osobą i podkreśla, że istotę miłości stanowi bezinteresowny dar z siebie. Te dwa aspekty wzajemnie się potwierdzają i przenikają. "Człowiek - pisze papież - najpełniej afirmuje siebie, dając siebie. To jest pełna realizacja przykazania miłości. To jest równocześnie pełna prawda o człowieku [...]. Nie przyjmując perspektywy daru z siebie samego, zawsze istnieje niebezpieczeństwo wolności egoistycznej" ${ }^{\prime \prime}$. Także w encyklice Ewangelum vitae można odnaleźć odwołanie się do perspektywy daru jako perspektywy miłości. W numerze 96 tejże encykliki papież Jan Paweł II przypomina, że miłość „pojmowana jako bezinteresowny dar z siebie, stanowi najprawdziwszy sens życia i wolności człowieka"10.

Myśl Soboru Watykańskiego II o miłości jako darze rozwija również w swoim nauczaniu Benedykt XVI. Podczas modlitewnego czuwania w Walencji papież mówił, że "człowiek został stworzony na obraz i podobieństwo Boże, aby kochać i realizuje w pełni siebie samego jedynie wtedy, gdy szczerze czyni z siebie dar dla innych"11. A zatem najgłębszą

7 Por. KDK 24.

8 Jan Paweł II, List apostolski „Mulieris dignitatem”, w: Wybór listów Ojca Świętego Jana Pawła II, t. 1, Kraków 1997, nr 7.

9 Jan Paweł II, Przekroczyć próg nadziei, Lublin 1995, s. 151.

${ }^{10}$ Jan Paweł II, Encyklika "Evangelium vitae”, Watykan 1995, nr 96.

${ }^{11}$ Benedykt XVI, Rodzina niezastapionym dobrem dla narodów. Przemówienie podczas 
zasadą miłości, stanowiącej o jej istocie jest bezinteresowny dar, przede wszystkim dar z tego, co człowiek ma najcenniejszego - swojego własnego człowieczeństwa. I wskazuje tenże papież, że takiej altruistycznej, bezinteresownej miłości człowiek ma uczyć się od Jezusa Chrystusa ${ }^{12}$. Owo „bezinteresowne dawanie siebie” jako wyraz miłości, do której uzdolniony jest człowiek, ma według nauczania Jezusa charakter radykalny i decydujący o losie człowieka. Jest ono istotnym warunkiem naśladowania Jezusa, którego życie i działalność ma charakter totalnego, nieodwołalnego daru z siebie, aż po ofiarę z własnego życia. „Nikt nie ma większej miłości od tej, gdy ktoś życie swoje oddaje za przyjaciół swoich" (J 15,13; por. 1 J 3,16) ${ }^{13}$.

Możliwość realizacji takiej miłości jako zasadniczego prawa chrześcijańskiej egzystencji wymaga także otwierania się na przyjęcie daru. „Miłość bowiem - jak twierdzi papież Jan Paweł II w Liście do Rodzin - jest dawaniem i przyjmowaniem daru. Nie można jej kupować ani sprzedawać. Można się nią tylko obdarowywać"14. Podobne myśli można odnaleźć w encyklice Benedykta XVI Deus caritas est: „Kto chce dawać miłość, sam musi ją otrzymywać w darze"15. Tak więc miłość polega nie tylko na poświęcaniu się dla drugiej osoby, na stawaniu się darem, na dawaniu siebie, ale także na przyjmowaniu daru. „Kto chce tylko dawać, a nie jest gotów przyjmować, kto chce tylko być dla drugich, a nie chce uznać, że sam żyje z dobrowolnego, nieoczekiwanego daru, czyjegoś daru «dla innych», ten zapoznaje zasadniczą cechę bytu ludzkiego i tak musi wprost zniszczyć prawdziwy sens bycia jednych dla drugich. Wszelkie przezwyciężanie siebie, by było owocne wymaga odbierania od kogoś drugiego"16. Miłość przyjmowana od innych osób oraz ofiarowana innym ludziom jest zatem najważniejszą potrzebą, której nie da się niczym zastąpić.

Prawda ta nabiera szczególnego normatywnego znaczenia w odniesieniu do wspólnoty małżeńskiej. Małżeństwo bowiem jest nie tylko

czuwania modlitewnego (Walencja - 8 lipca 2006), „L'Osservatore Romano” (wyd. pol.) 27 (2006), nr 9-10, s. 14.

12 Por. DCE 12.

${ }^{13}$ Por. A. Nossol, Chrześcijańska proegzystencja - istnienie i życie dla innych, „Collectanea Theologica" 49 (1979), nr 2, s. 13-21.

14 Jan Paweł II, List do Rodzin, Rzym 1994, nr 11 (dalej: LdR).

${ }^{15}$ DCE 7.

${ }^{16}$ J. Ratzinger, Wprowadzenie w chrześcijaństwo, tłum. Z. Włodkowa, Kraków 1996, s. $247-248$. 
więzią życia i miłości, ale wola zawarcia małżeństwa jest wolą wzajemnego oddania i przyjęcia ${ }^{17}$. Takie rozumienie małżeństwa zawarte w Konstytucji Gaudium et spes przejęło również nowe prawo kanoniczne: „ZZgoda małżeńska jest aktem woli, którym mężczyzna i kobieta w nieodwołalnym przymierzu wzajemnie się sobie oddają i przyjmują w celu stworzenia małżeństwa"18. Sama formuła przy zawieraniu małżeństwa brzmi wprawdzie: "Ja biorę ciebie za żonę", "Ja biorę ciebie za męża”, zawiera jednak w sobie znacznie głębsza treść, bo właściwie jej sensem jest: "Ja się tobie oddaję jako mąż i przyjmuję jako żonę", "Ja się tobie oddaję jako żona i przyjmuję jako męża". Zachodzi zasadnicza różnica pomiędzy "Ja biorę ciebie za męża/żonę" a "Ja się tobie oddaję jako mąż/ żona". Nie bez znaczenia było by dołożenie do tej formuły wyrażającej oddanie się przymiotnika "bezbronny”, „bezbronna”. "Ja się tobie oddaję bezbronny jako mąż i przyjmuję cię bezbronną jako żonę". "Ja się tobie oddaję bezbronna jako żona i przyjmuję cię bezbronnego jako męża".

Dlaczego ten przymiotnik? Bo z chwilą zawarcia małżeństwa małżonkowie stają się bezbronni. Mogą się wzajemnie albo uszczęśliwić, albo bez kresu unieszczęśliwić. Mogą być wzajemnie albo prawdziwie oddani, to znaczy bardzo miłujący, albo też mogą być dla siebie okrutni. W różny zresztą sposób. Jeżeli są problemy w miłości małżeńskiej, to mają one źródło właśnie w braku oddania. Jeśli coś się „psuje” w małżeństwie, to znaczy, że mąż i żona zaczęli szukać siebie. A św. Paweł pisze, że „miłość nie szuka swego" (1 Kor 13,5). Prawdziwa miłość uwalania od szukania siebie, od egoizmu, izolacji, pozwala zapomnieć o sobie i przekraczać siebie. Wyrzeczenie się siebie, dar z siebie, typowe dla prawdziwej miłości małżeńskiej, zakładają pełną wartość osoby współmałżonka, jego piękno i drogocenność. Dowodzą też, że współmałżonek, w znaczeniu obiektywnym jest warty miłości. Miłość małżeńska zaczyna wtedy być rozumiana jako wzajemne oddanie się i przyjęcie przez mężczyznę i kobietę na sposób duchowy i cielesny ${ }^{19}$.

W konsekwencji taka miłość - jak uczy papież Benedykt XVI we wspomnianej encyklice Deus caritas est - domaga się definitywności, w sensie wyłączności i w sensie na zawsze $e^{20}$. Miłość bowiem obejmuje

17 Por. KDK 48.

${ }^{18}$ Kodeks Prawa Kanonicznego, Poznań 1984, kan. 1057, par. 2.

${ }_{19}$ Por. A. Sarmiento, Matżeństwo chrześcijańskie. Podręcznik teologii matżeństwa i rodziny, Kraków 2002, s. 48-55.

${ }^{20}$ Por. DCE 6. 
całość ludzkiej egzystencji w każdym jej wymiarze, także w wymiarze czasu i ukierunkowana jest ostatecznie na wieczność. Taka miłość pozwoli odnaleźć wspólnocie małżeńskiej najgłębszy sens ich życia, a także odkryć Boga, który w tajemnicy wywyższenia Chrystusa na krzyżu, dopełnił dzieła zbawienia i objawił prawdziwą miłość.

\section{MAŁŻEŃSKA MIŁOŚĆ 1 „KTOŚ TRZECl” - NAJWYŻSZY}

Miłość - jak już zostało powiedziane - zawsze wzywa czy domaga się wzajemności. A ponadto tam, gdzie jest odwzajemniony dar a więc i jego wzajemne przyjęcie zawsze jest „ktoś trzeci”. Wierzący wie, że tym Kimś Trzecim jest przede wszystkim sam Bóg, który jest źródłem wszelkiej miłości. Uwydatnił to wyraźnie papież Paweł VI w encyklice Humanae vitae: „Miłość małżeńska najlepiej objawia nam swoją prawdziwą naturę i godność wtedy, gdy rozważymy, że początek swój czerpie ona - jakby z najwyższego źródła - z Boga, który jest Miłością i Ojcem, od 'którego bierze swe imię wszelkie ojcostwo na niebie i na ziemi' (Ef $3,15)^{\prime 21}$. Wspólnota małżeńska nie jest wynikiem jakiejś niesłusznej ingerencji społeczeństwa czy władzy, ani zewnętrznym narzuceniem jakiejś formy, ale stanowi wymóg wewnętrzny przymierza miłości małżeńskiej, które potwierdza się publicznie jako jedyne i wyłączne dla dochowania w ten sposób pełnej wierności wobec zamysłu Boga Stwórcy ${ }^{22}$.

Tak więc małżeństwo jest instytucją i wspólnotą naturalną powstałą na bazie miłości i pochodząca od Boga Stwórcy. To Bóg ustalił „drogę człowieka do małżeństwa. Jest to „droga” miłości. To sam Bóg łączy miłość mężczyzny i kobiety w jedność wspólnoty małżeńskiej (por. Mt 19,6) $)^{23}$. W Konstytucja Duszpasterskiej o Kościele w świecie współczesnym Gaudium et spes Soboru Watykańskiego II można przeczytać, że „miłość małżeńska zostaje przyjęta, zespolona z miłością Boga"24. Sama zatem logika i dynamika miłości zwraca osobę mężczyzny i kobiety ku Bogu, który jest miłością - źródłem i celem miłości. Miłość bowiem zmierza

${ }^{21}$ Paweł VI, Encyklika „Humanae vitae”, Kraków 1968, nr 8 (dalej: HV).

22 Por. FC 11.

${ }^{23}$ Kongregacja ds. Wychowania Katolickiego w dokumencie Wytyczne wychowawcze w odniesieniu do ludzkiej miłości stwierdza: „Mężczyzna i kobieta [...] poślubieni, uczestniczą w miłości stwórczej Boga, przeżywając wspólnotę z Nim poprzez druga osobę" (nr 26).

${ }^{24} \mathrm{KDK} 48$. 
do urzeczywistnienia doskonałej jedności osób, a ta jedność mężczyzny i kobiety jest możliwa jedynie w Bogu i przez Boga. Miłość mężczyzny i kobiety - ze swej istoty - prowadzi więc ku Bogu²5.

Ta prawda obliguje małżonków do przyjęcia moralnej odpowiedzialności za objawienie w świecie całym swoim życiem prawdy Boskiej miłości. Bóg stwarzając ich jako jedność to znaczy jako małżeństwo, czyni ich obrazem siebie. W ten sposób czyni ich także głosicielami tej samej miłości, która ich stworzyła. Miłość dana przez Boga człowiekowi w akcie powołania staje się zadaniem i treścią osobowej relacji mężczyzny i kobiety. Zadanie to zostaje przyswojone świadomości i wolności człowieka na drodze samego doświadczenia etycznego. Miłując bowiem, poznaje się prawdę o miłości. Istotą miłości jest pragnienie dobra umiłowanej osoby. Jest ot pragnienie bezinteresowne, dane jakby w nurcie miłości idącym z góry. Bóg stwarzając osobę jako podmiot miłości, obdarza ją swoim pragnieniem. Kiedy w autentycznej miłości pragnienie Boga staje się własnym pragnieniem, czyli treścią tego podstawowego dobra, którym jest miłość, wtedy staje się oczywiste, że miłujący pragnie nie innego dobra, lecz samego Boga dla swojej umiłowanej osoby. Mężczyzna i kobieta złączeni jednym powołaniem pragną więc dla siebie nawzajem Boga ${ }^{26}$.

Taka jest prawda ich jedności, lecz jest to jednocześnie zadanie postawione ich wolności. Ich wola ma za zadanie zawsze na nowo zespalać się z tym aktem miłości, którym Bóg uczynił ich tym, czym są, i który nadal ich czyni coraz doskonalszym obrazem własnej jedności. Jednocześnie mężczyzna i niewiasta wchodząc w nurt Bożej miłości objawionej w stworzeniu przeżywają swoją egzystencję jako istnienie dla Boga. Wyrażają to tym samym aktem woli, którym akceptują daną im przez Boga małżeńską formę istnienia. Być stworzonym, to być obdarowanym przez Stwórczą Miłość. Człowiek zatem w pełni stworzony i dla tego reprezentujący Boga wobec całego stworzenia, rozpoznaje w swojej osobowości dwa kierunki pragnienia. Jest to pragnienie Boga dla człowieka i pragnienie człowieka dla Boga. Odkrywa w ten sposób swoją tożsamość w dążeniu do darowania Boga człowiekowi oraz do darowania człowieka Bogu ${ }^{27}$. Jan Paweł II w Familiaris consortio stwierdza:

25 Por. A. Dziuba, Stużebny wymiar powotania matżeńskiego, „Chrześcijanin w Świecie" 12 (1982), nr 8, s. 6-7.

26 Por. A. Bohdanowicz, Istota mitości, s. 28.

27 Por. J. Bajda, Konsekracja ciata w aspekcie powotania kobiety, w: O Jana Pawta II teologii ciała, t. I, red. T. Styczeń, Lublin 1981, s. 196-197. 
„Główny przekaz objawienia: ‘Bóg miłuje swój lud', zostaje wypowiedziany również zwykłymi i konkretnymi słowami, poprzez które mężczyzna i kobieta wyrażają swoją miłość małżeńską. Więź ich miłości staje się obrazem i znakiem Przymierza łączącego Boga z jego ludem"28.

Przymierze Boga z ludźmi zostało ostatecznie zrealizowane przez Jezusa Chrystusa w Nowym Przymierzu. W Starym Testamencie małżeństwo symbolizowało Stare Przymierze. W Chrystusie małżeństwo ochrzczonych staje się sakramentem, czyli znakiem Nowego i wiecznego Przymierza oraz narzędziem realizacji zamysłu Boga-Stwórcy. Tak więc małżeństwo jest szczególnym miejscem spotkania się natury i łaski, ponieważ należy do porządku naturalnego i nadprzyrodzonego. Małżeństwo jak „sakrament stworzenia” urzeczywistnia się jako „sakrament odkupienia". Przez Chrystusowe odkupienie małżeństwo jakby na nowo zostaje zrodzone i odnowione ${ }^{29}$.

W sakramencie małżeństwa Chrystus włącza miłość małżonków w swoją miłość do Kościoła, dzięki czemu otrzymują oni zdolność do kochania się tak, jak Chrystus umiłował każdego człowieka. Małżeństwo podniesione do godności sakramentu jest darem miłości Wszechmogącego Boga do ludzi. Jest też wezwaniem małżonków do miłości na wzór samego Chrystusa. W Liście do Efezjan św. Paweł ukazuje nieskończoną miłość Chrystusa do Kościoła i podaje ją jako wzór dla wszystkich małżeństw: „mężowie, miłujcie żony, bo i Chrystus umiłował Kościół i wydał za niego samego siebie" (Ef 5,25). Przez sakrament małżeństwa miłość między dwojgiem ludzi zostaje włączona w miłość, którą Chrystus w sposób nieodwołalny miłuje Kościół. Papież Benedykt XVI pisze o tej analogii w adhortacji Sacramentum caritatis: „miłość małżeńska jest znakiem sakramentalnym miłości Chrystusa do swego Kościoła, miłości, która ma swój punkt kulminacyjny w Krzyżu”30. A więc Chrystus umiłował Kościół aż do oddania swego życia. Małżonkowie uczą się takiej miłości mocą wielkiego sakramentu. Mężczyzna i kobieta żyjący w małżeństwie uczestniczą w śmierci i zmartwychwstaniu Chrystusa. W krzyż i zmartwychwstanie Chrystusa wpisana jest miłość małżeńska. Misterium paschalne skłania małżonków do ustawicznego wysiłku mającego na celu

28 FC 12.

29 Por. M. Słowik, Rodzina wspólnotą religijno-moralną, Niepokalanów 1997, s. $33-41$.

30 Benedykt XVI, Adhortacja apostolska "Sacramentum caritatis”, Tarnów 2007, nr 27. 
„odkupienie" ich miłości przez zwycięstwo nad grzechem. Natomiast wniebowstąpienie inspiruje małżonków do radości i nadziei ${ }^{31}$.

Sakramentalność małżeństwa włącza więc małżonków w nadprzyrodzony porządek zbawienia, staje się rzeczywistością i znakiem zbawienia. Małżeństwo jako znak zbawienia jest jednocześnie środowiskiem zbawienia. „W" małżeństwie i „przez” małżeństwo dokonuje się zbawienie człowieka. Małżeństwo staje się więc miejscem łaski i uświęcenia. „Właściwym źródłem i pierwotnym środkiem uświęcenia małżeństwa i rodziny chrześcijańskiej jest sakrament małżeństwa"32. Sakramentalne "tak" wypowiedziane przez małżonków staje się źródłem łaski i wezwaniem, któremu małżonkowie mocą tylko swojej miłości nie byliby w stanie sprostać. Dlatego właśnie Chrystus podnosi ów związek do rangi sakramentu i sam wchodzi w miłosną relację każdej pary małżeńskiej3. Przysięga małżeńska potwierdza i wyraża więź i wzajemną miłość - w mocy Jezusa Chrystusa. Dzięki sakramentalnej obecności Chrystusa i dobrowolnie złożonej przysiędze, w której małżonkowie oddają się sobie wzajemnie, małżeństwo staje się świętą wspólnotą. Jest ono komunią osób zjednoczonych miłością Chrystusa. To sam Chrystus kocha w nich i przez nich. Chrystus „w sakramencie małżeństwa daje «serce nowe» tak, że małżonkowie nie tylko mogą przezwyciężyć «zatwardziałość serca» ale równocześnie i nade wszystko dzielić pełną i ostateczną miłość Chrystusa, nowe i wieczne Przymierze, które stało się ciałem"34.

Nie wolno przy tym zapominać, że „dar Jezusa Chrystusa nie wyczerpuje się $\mathrm{w}$ samym sprawowaniu sakramentu małżeństwa, ale towarzyszy małżonkom przez całe ich życie"35. Sakramentalność pozwala małżonkom rozwijać ich wzajemną miłość dzień po dniu. Na ile małżonkowie będą otwarci na Chrystusa, na tyle Jego łaska będzie miała wpływ na tworzenie małżeńskiej komunii miłości. W tym kontekście staje się zrozumiałe, że sakrament małżeństwa jest nie tylko wielkim darem dla małżonków, ale także zobowiązaniem. Małżonkowie są zobowiązani do współpracy z łaską sakramentalną, by „nie była przyjmowana na

${ }^{31}$ Por. J. Grześkowiak, Matżeństwo a misterium Chrystusa, "Ateneum Kapłańskie” 1-2 (1985), s. 195-201; A. Szafrański, Łaska sakramentu matżeństwa, w: Matżeństwo i rodzina, red. A. Szafrański, Lublin 1985, s. 105-106.

${ }^{32}$ FC 56.

${ }_{33}$ Por. D. Kuglin, Miłość fundamentem życia rodzinnego i chrześcijańskiego, „Sosnowieckie Studia Teologiczne" 9 (2009), s. 128-131.

${ }^{34}$ FC 20.

35 Tamże, nr 56. 
próżno" (2 Kor 6,1). Są to zobowiązania natury moralnej. Pod takim warunkiem sakrament tworzy i pozwala rozwijać prawdziwą komunię miłości małżeńskiej ${ }^{36}$.

Z powyższych słów jasno więc wynika, że miłość małżeńska jest mocno zakorzeniona w Chrystusie i Jego łasce. Chrystus udziela łaski, by małżeństwo było prawdziwym przymierzem miłości, ale też domaga się współpracy małżonków. Małżonkowie jako szafarze sakramentu zapraszają Chrystusa do swojej wspólnoty. Chrystus przyjmuje to zaproszenie. Dzięki obecności Chrystusa miłość małżeńska rozwija się, dojrzewa, staje się źródłem pokoju i szczęścia oraz widzialnym znakiem zbawienia.

\section{MAŁŻEŃSKA MIŁOŚĆ 1 „KTOŚ TRZECl” - DZIECKO}

W miłości między mężczyzną i kobietą tym „kimś trzecim” jest nie tylko Bóg. Jest nim też dziecko, czy dzieci. Małżeństwo i miłość małżeńska z natury swej skierowane są na rodzenie i wychowywanie potomstwa $^{37}$. Miłość między mężczyzną i kobietą jest miłością pary osób, która właśnie jako para jest zdolna do rodzicielstwa. Zdolność przekazywania życia, a więc męskość i kobiecość jest jakąś właściwością wyznaczającą niezwykłą godność człowiekowi właśnie przez to, że w określonych warunkach czynią go uczestnikiem stwórczej wszechmocy Boga. Na tę fundamentalną prawdę wskazał Jan Paweł II w adhortacji Familiaris consortio: „Bóg powołuje małżonków do szczególnego uczestnictwa w swej miłości, a zarazem w swojej mocy Stwórcy i Ojca poprzez ich wolną i odpowiedzialną współpracę w przekazywaniu życia"38.

Tak więc Bóg dał człowiekowi nie tylko „podobieństwo” do Siebie, ale także pozwolił mu uczestniczyć w swej boskiej aktywności. Boża miłość była i jest zawsze płodna i owocna. W Bożym planie ludzka miłość w sobie właściwym zakresie może być również owocna i płodna. Bóg połączył dar życia z miłością małżeńską. Rodzicielstwo jest uwieńczeniem miłości małżonków, ale równocześnie jest ich podstawowym powołaniem i moralnym obowiązkiem ${ }^{39}$. Małżonkowie nie mogą więc aspektu prokreacyjnego wymazywać czy brać w nawias. Należy on bo-

\footnotetext{
${ }^{36}$ Por. M. Słowik, Rodzina wspólnota, s. 49-51.

${ }^{37}$ KDK stwierdza, że „dzieci są najcenniejszym darem małżeństwa” (nr 50).

${ }^{38}$ FC 28; por. Katechizm Kościoła Katolickiego, Poznań 1994, nr 2205.

${ }^{39}$ Por. KDK 48.
} 
wiem do integralnej części miłości małżeńskiej. Miłość i rodzicielstwo to wewnętrzny wymóg osoby i małżeńskiej komunii miłości ${ }^{40}$.

W miłości małżeńskiej odzwierciedla się miłość Boga do człowieka. Bóg jest źródłem miłości, jest jej siłą i ostatecznym przeznaczeniem. Zarówno miłość małżeńska, jak i prokreacja ludzka stanowią znak i świadectwo sakramentu miłości Boga Ojca. Jak już zostało powiedziane małżonkowie uczestniczą w Bożej miłości, w Jego akcie stwórczym właśnie poprzez prokreację. Dlatego akt małżeński nie może być aktem panowania, ale służby, podejmowanej w celu prokreacji nowego życia. Ten obraz płodnej miłości małżeńskiej, która uczestniczy w odwiecznym planie Boga, wskazuje na fakt, iż prokreacja ludzka musi być aktem wolnym, świadomym i odpowiedzialnym. Szczególnie odpowiedzialność ta jawi się jako współpraca z mocą i wolą Boga w stwarzaniu nowej osoby ${ }^{41}$.

Powierzenie aktu prokreacyjnego parze małżeńskiej jest znakiem ogromnego zaufania ze strony Boga wobec ludzi. Małżonkowie podważają to zaufanie, gdy stosują antykoncepcję; nie chcą w ten sposób pozwolić Bogu na dokonanie aktu stwórczego. Antykoncepcja oznacza więc odmowę pełnienia misji przekazywania życia. Antykoncepcja sprzeciwia się również w sposób poważny czystości małżeńskiej, zdradza ona i fałszuje miłość, jest zaprzeczeniem wzajemnego daru małżonków ${ }^{42}$. „Przez działanie antykoncepcyjne - jak pisze Jan Paweł II w adhortacji Familiaris consortio - małżonkowie nie tylko odrzucają otwartość na życie, ale fałszują wewnętrzną prawdę miłości małżeńskiej powołanej do całkowitego daru z siebie" ${ }^{\prime 43}$. Ów dar z siebie zostaje naruszony i odarty z bogactwa swej naturalnej i etycznej wartości międzyosobowej. Następuje jego zubożenie, a raczej traci on swe twórcze odniesienie do miłości i daru życia. Swoisty egoizm, akceptowany często przez oboje małżonków, neguje dynamikę wzajemnych odniesień. Stają się one mniej twórcze, a nawet mogą stopniowo wywołać działania negatywne, prowadząc w niektórych przypadkach do rozpadu małżeństwa. Słuszne jest więc wołanie papieża

40 Por. D. Tettamanzi, Encyklika "Humanae vitae” w nauczaniu Jana Pawła II, „Communio" 13 (1993), nr 3, s. 154-155.

41 Por. J. Nagórny, Istota odpowiedzialnego rodzicielstwa, w: Odpowiedzialni za życie i miłość, red. E. Burzyk Bielsko-Biała 1994, s. 27-57. Por. także: J. Orzeszyna, Odpoziedzialne rodzicielstwo, w: Jan Paweł II, Encyklopedia Nauczania Moralnego, red. J. Nagórny, K. Jeżyna, Radom 2005, s. 370-373.

42 Por. A. Drożdż, Permisywizm moralny, Kielce 2005, s. 301-304. Por. także: A. J. Katolo, Bezdroża antykoncepcji, Lublin 2011, s. 29.

${ }^{43}$ FC 32. 
Benedykta XVI 10 maja 2008 r. do uczestników kongresu z okazji 40-lecia encykliki Humanae vitae: "Żadna mechaniczna technika nie może zastąpić aktu miłości dwojga małżonków, którzy dzielą się sobą na znak większej tajemnicy, w której są głównymi postaciami i współuczestnikami stworzenia [...]. Jako wierzący nie możemy nigdy dopuścić do tego, żeby dominacja techniki naruszyła jakość miłości i świętość życia"44.

Tak więc prawdziwa miłość nie może być nigdy ograniczona żadnymi sztucznymi środkami obezwładniającymi. Jedynym sposobem regulacji poczęć jest naturalna metoda, która wypływa z biologicznego rytmu płodności kobiety ${ }^{45}$. Naturalna metoda regulacji poczęć, w myśl słów Jana Pawła II, stanowi „akceptację cyklu osoby, to jest kobiety, a co za tym idzie akceptację dialogu, wzajemnego poszanowania, wspólnej odpowiedzialności i panowania nad sobą. Przyjęcie cyklu i dialogu oznacza następnie uznanie charakteru duchowego i cielesnego zarazem komunii małżeńskiej, jak również przeżywanie miłości osobowej w wierności, jakiej ona wymaga"46. Na małżonkach nie ciąży więc obowiązek nieograniczonej płodności, mogą oni i wręcz powinni ją regulować, uwzględniając warunki psychiczne i fizyczne oraz ekonomiczne i społeczne, w jakich żyją. Ich rodzicielstwo jest odpowiedzialne nie tylko wtedy, gdy decydują się przyjąć większą liczbę potomstwa, lecz także wtedy, kiedy dla poważnych racji postanawiają, okresowo lub na czas nieograniczony, unikać poczęcia nowego życia i w tym celu rezygnują ze współżycia, bądź też podejmują je w okresie fizjologicznej niepłodności kobiety ${ }^{47}$.

W tej perspektywie można za encykliką Humanae vitae powiedzieć, że ten, „kto [...] korzysta z daru miłości małżeńskiej z poszanowaniem praw przekazywania życia, ten uznaje, że nie jest panem Źródeł życia, ale raczej sługą planu ustalonego przez Stwórcę ${ }^{\prime 48}$. Rodzicielstwo jawi się $\mathrm{w}$ ten oto sposób nie tylko jako dar, lecz także jako zobowiązanie

${ }^{44}$ Benedykt XVI, Encyklika, która stała się znakiem sprzeciwu. Przemówienie do uczestników kongresu z okazji 40-lecia encykliki Pawta VI "Humanae vitae" (Watykan - 10 maja 2008), „L'Osservatore Romano” (wyd. pol.) 29 (2008), nr 6, s. 39-40.

${ }^{45}$ Por. szerzej: W. Fijałkowski, Biologiczny rytm płodności a regulacja urodzeń, Warszawa 1978; W. Fijałkowski, Ekologia rodziny. Ekologiczna Odnowa Prokreacji, Kraków 2001; W. B. Skrzydlewski, Planowanie rodziny - wyzwanie moralne, Kraków 1998; U. Dudziak, Metody planowania rodziny. Naturalne Planowanie Rodziny, Kraków 2001; J. Rötzer, Sztuka planowania rodziny, Warszawa 2005.

${ }^{46}$ FC 32.

${ }^{47}$ Por. KDK 50; HV 10.

${ }^{48} \mathrm{HV} 13$. 
moralne. Małżonkowie mają kształtować w sobie właściwe postawy rodzicielskie, wpisane w naturę ludzką. Kształtują je prawidłowo, gdy składają siebie samych $\mathrm{w}$ darze i szukają pomocy u Boga.

Trzeba jednak pamiętać, że miłość, która skłoniła małżonków do zawarcia małżeństwa i która stanowi źródło życia małżeńskiego jest również duszą i normą wychowania dzieci ${ }^{49}$. Podkreślił to papież Jan Paweł II w Familiaris consortio stwierdzając, że najgłębszym elementem charakteryzującym zadanie wychowawcze rodziców jest właśnie „miłość ojcowska i macierzyńska, która znajduje w dziele wychowawczym wypełnienie doskonałej służby życiu: miłość rodzicielska od początku staje się duszą, a przez to i normą, która inspiruje i nadaje kierunek całej konkretnej działalności wychowawczej"50. Podobnie uczył papież w Liście do Rodzin: „W miłości znajduje oparcie i ostateczny sens cały proces wychowawczy jako dojrzały owoc miłości rodzicielskiej. Poprzez wszystkie trudy, wszystkie cierpienia i zawody, jakie idą w parze z wychowaniem człowieka, miłość wciąż zdaje wielki egzamin"51.

Jako współpracownicy Boga małżonkowie otrzymują misję strzeżenia, objawiania i przekazywania miłości. Małżonkowie pełnią rolę szkoły miłości, przygotowującą człowieka do zrealizowania głównych zadań życiowych ${ }^{52}$. Fundamentalnym zadaniem wychowawczym rodziny chrześcijańskiej w odniesieniu do miłości jest ukazanie istoty tej miłości. Chodzi mianowicie o to, że wychowanie do miłości jest zawsze najpierw wychowaniem do tego, by człowiek umiał odkryć i przyjąć miłość Boga jako dar, by umiał w duchu dziecięcej ufności przyjąć miłość, którą został obdarowany. A następnie by umiał ten dar w sobie rozwinąć i przekazać innym, by tego daru miłości nie zmarnował.

Dla chrześcijanina wychowanie do miłości przybiera zawsze rys chrystocentryczny. W Chrystusie każdy człowiek wierzący rozpoznaje doskonały obraz miłości Boga i człowieka, a jednocześnie otrzymuje od Niego moc, aby mógł miłować tak, jak On sam miłuje. Człowiek, który wierzy, że jego zdolność miłości jest darem Boga, wie jednocześnie, że otwarcie się na drugą osobę bez jednoczesnego otwarcia się na Chrystusa jest zafałszowaniem chrześcijańskiego sensu miłości. Obowiązkiem

49 Por. J. Orzeszyna, Miłość normą życia rodzinnego, „Polonia Sacra” 3 (1999), nr 4, s. 153-166.

\footnotetext{
${ }^{50} \mathrm{FC} 36$.

${ }^{51}$ LdR 16.

${ }^{52}$ Por. M. Dziewiecki, Wychowanie w dobie ponowoczesności, Kielce 2002, s. 51-67.
} 
małżonków jest więc uczyć człowieka otwierać się na miłość Chrystusa, która przemienia i uczyć kochać tą miłością, którą Chrystus jako pierwszy ukochał każdego człowieka. Małżeństwo jest uprzywilejowanym środowiskiem, gdzie każda osoba na wzór Chrystusa uczy się ofiarować i przyjmować miłość. Przedmiotem tej miłości mają być wszyscy ludzie. Wszyscy bowiem zostali odkupieni przez Chrystusa i objęci Jego dziełem miłości. Mówił o tym papież Benedykt XVI we wspomnianym już przemówieniu do rodzin w Walencji: „Gdy rodzina nie jest zamknięta w sobie dzieci uczą się, że każda osoba jest godna miłości oraz, że wszystkich ludzi łączy podstawowe i powszechne braterstwo" ${ }^{\prime \prime 53}$.

W tym kontekście miłość, która stoi u podstaw wychowania w rodzinie powinna być wymagająca: „Miłość jest prawdziwa wówczas, gdy tworzy dobro osób i wspólnot, gdy tym dobrem obdarowuje drugich. Tylko zaś człowiek, który umie wymagać od siebie samego $\mathrm{w}$ imię miłości, może także wymagać miłości od drugich"54. Wymagania te muszą być roztropne, bo tylko $\mathrm{w}$ ten sposób będą owocem miłości. Tylko $\mathrm{w}$ atmosferze miłości, która przekłada się na zaufanie łączące małżonków $\mathrm{z}$ dziećmi, a wyrażające się $\mathrm{w}$ postawie radości, pogody i mobilizacji, wymagania mogą być właściwe odczytane i przyjęte.

W tej perspektywie trzeba stwierdzić, że tylko odpowiedzialna, wymagająca, pełna poświęcenia i ofiary postawa małżonków-rodziców wobec dziecka może wpływać pozytywnie na jego sposób rozumienia i uczenia się prawdziwej miłości. Tylko taka postawa małżonków nauczy dzieci przezwyciężania własnego egoizmu i otwierania się na potrzeby innych. Do tego potrzebna jest łaska, na której buduje się miłość oraz konieczne jest poddawanie się działaniu Ducha Świętego, który jest siłą sprawczą każdej prawdziwej miłości.

\section{PODSUMOWANIE}

Jeżeli we współczesnym świecie daje się zauważyć, upadek autorytetów, kryzys instytucji małżeństwa i rodziny, dewaluację miłości małżeńskiej, jeżeli jest coraz więcej ludzi, którzy nie chcą zawierać małżeństwa, świadczy to po prostu o tym, że nie wiedza, co to jest miłość? A może i nie potrafią miłować? Dlatego przedstawiona refleksja miała na celu

${ }^{53}$ Benedykt XVI, Rodzina niezastapionym dobrem dla narodów, s. 14-15.

${ }^{54}$ LdR 14. 
pomóc odkryć współczesnemu człowiekowi, czym jest prawdziwa miłość i ukazać wartość i piękno miłości małżeńskiej, a szczególnie uwypuklić unifikująca, integrującą rolę miłości w życiu małżonków.

Z przeprowadzonych rozważań wynika, że prawdziwa miłość polega na wzajemnym i szczerym obdarowywaniu się sobą. Osoba kochająca daje siebie $\mathrm{w}$ bezinteresownym darze osobie kochanej i jednocześnie przyjmuje od niej dar. Darem są tu osoby, mężczyzna i kobieta. Miłość bezinteresowną, ofiarującą szczęście uważa się więc za jedyną formę miłości godną osoby ludzkiej. W niej odsłania się prawda, że „Bóg jest miłością" (1 J 4,16). Taka koncepcja miłości wyraźnie uwypukla jej integrującą rolę także w życiu małżeńskim. Miłość małżeńska wyraża się przez trwały i nieodwołany dar osoby dla osoby. Umożliwia go sakramentalne uczestnictwo małżonków w najbardziej bezinteresownym darze, jakim jest odkupienie za cenę Krwi Chrystusa. Miłość małżeńska zakorzeniona w Chrystusie jest gotowa do wyrzeczeń, zdolna wznieść się na wyżyny, przezwyciężyć każdą słabość i kruchość. Zgodnie z logiką bezinteresownego daru komunia małżeńska staje się też komunią rodzicielską. W miłości małżeńskiej chodzi bowiem o to, aby mężczyzna i kobieta stawali się komunią osób, otwartą na przyjęcie daru nowego życia. Otwartość na płodność jest kryterium autentyczności miłości małżeńskiej. Unifikująca rola miłości w życiu małżeńskim odnosi się zatem do wszystkich sfer życia małżonków, nie wyłączając prokreacji. Małżonkowie przeżywający w takim duchu wzajemną miłość stają się małym, ale autentycznym Kościołem domowym. Tak rozumiana miłość najpełniej też odpowiada najgłębszym ludzkim potrzebom.

Dokonane studium, wskazuje na aktualność zagadnienia w odniesieniu do współczesnego Kościoła i świata. Kwestia odnalezienia integralnego wymiaru miłości we wspólnocie małżeńskiej jest tematem ciągle niewyczerpanym i otwartym. Można więc żywić nadzieję, że przedłożone refleksje, staną się swego rodzaju zaproszeniem do bardziej pogłębionego studium omówionych problemów, a przez to ukażą jak wielkie i ważne zadania stoją wciąż przed teologią moralną i duchowością w upowszechnianiu i odkrywaniu wartości miłości w życiu małżeńskim. Jeżeli dodatkowo lektura niniejszego studium zachęci, szczególnie małżonków, do podjęcia wysiłku do codziennego pielęgnowania miłości, tzn. do właściwego odpowiadania na dar, jakim jest miłość, to zamierzenia, jakie postawiono $\mathrm{w}$ niniejszym opracowaniu, będą w pełni osiągnięte. 
Streszczenie. Integrująca rola miłości we wspólnocie życia małżeńskiego. Podstawowym i wrodzonym powołaniem każdej istoty ludzkiej jest miłość. Miłość jest też jednym z najgłębszych źródeł małżeńskiej wspólnoty. Niestety, współczesna mentalność przyczynia się do degradacji wartości miłości w życiu małżeńskim. Szczególnie przekaz medialny często zniekształca obraz prawdziwej miłości małżeńskiej. Dlatego niniejsze opracowanie miało na celu pomóc odkryć współczesnemu człowiekowi, czym jest prawdziwa miłość i ukazać integrującą rolę miłości w życiu małżonków.

Z przeprowadzonych rozważań wynika, że prawdziwa miłość polega na wzajemnym i szczerym obdarowywaniu się sobą. Osoba kochająca daje siebie w bezinteresownym darze osobie kochanej i jednocześnie przyjmuje od niej dar. Miłość bezinteresowną, ofiarującą szczęście uważa się więc za jedyną formę miłości godną osoby ludzkiej.

Taka koncepcja miłości wyraźnie uwypukla jej integrującą rolę także w życiu małżeńskim. Miłość małżeńska wyraża się przez trwały i nieodwołany dar osoby dla osoby. Umożliwia go sakramentalne uczestnictwo małżonków w najbardziej bezinteresownym darze, jakim jest odkupienie za cenę Krwi Chrystusa. Miłość małżeńska zakorzeniona w Chrystusie jest gotowa do wyrzeczeń i ofiar. Zgodnie z logiką bezinteresownego daru komunia małżeńska staje się też komunią rodzicielską. Unifikująca rola miłości w życiu małżeńskim odnosi się zatem do wszystkich sfer życia małżonków, nie wyłączając prokreacji. Tak rozumiana miłość najpełniej też odpowiada najgłębszym ludzkim potrzebom.

Słowa kluczowe: Stwórca; miłość; dar; małżeństwo; sakrament; dziecko; wychowanie.

Abstract. Integrating the role of love married life in the community. Fundamental and innate vocation of every human being is love. Love is also one of the deepest sources of marital community. Unfortunately, the modern mentality contributes to the degradation of the value of love in married life. Especially communication media often distorts the true picture of conjugal love. Therefore, this study was designed to help modern man to discover what true love is and show love's, integrating role in the lives of the spouses.

From the performed considerations that true love is mutual and sincere selfgiving of themselves. Loving person gives himself in selfless gift to the person loved, and at the same time takes from her gift. Selfless love, offering luck is therefore considered the only form of love worthy of the human person.

Such a concept of love clearly highlights its integrating role also in the married life. Conjugal love is a durable and not canceled by the gift of the person to person. This allows him the sacramental participation of spouses in the most gratuitous gift of a redemption for the price of the Blood of Christ. Conjugal love rooted in Christ is ready for sacrifices and victims. According to the logic of selfless gift of conjugal communion becomes a communion of parental responsibility. 
Unifying role of love in married life, therefore, applies to all spheres of life of the spouses, not excluding procreation. Thus understood, love it most fully corresponds to the deepest human needs.

Keywords: Creator; love; gift; marriage; sacrament; child; upbringing. 